
\title{
$\mathrm{Cr}-\mathrm{Mo}-\mathrm{V}$ 鍛鋼のクリープキャビティの生成・ “誰 成長挙動と破断延性に影響する治金的因子 \\ /1//////I/I/I/I////
}

$$
\text { 角 屋 好 } \text { 邦 }^{*} \text {. 後 藤 徹 }{ }^{*}
$$

\section{Metallurgical Factors Affecting Creep Cavitation Behavior and Rupture Ductility of Cr-Mo-V Steel Forging}

Yoshikuni KADOYA and Toru GoTo

\section{Synopsis :}

In order to clarify metallurgical factors affecting creep rupture ductility of $\mathrm{Cr}-\mathrm{Mo}-\mathrm{V}$ steel, creep tests for the specimens with actual rotor materials differing in quenching temperature and also in impurity content were carried out at $550^{\circ} \mathrm{C}-210 \mathrm{MPa}$ and $575^{\circ} \mathrm{C}-160 \mathrm{MPa}$. Creep properties were compared and also nucleation-growth behavior of creep cavities during creep and rupture ductility were investigated. The obtained results are as follows :

(1) The high-purity materials have the best rupture ductility among as-heat-treated materials quenched at $940-970^{\circ} \mathrm{C}$ and show rupture elongation higher than $10 \%$. Other low-purity materials show rupture elongation lower than $10 \%$. The decrease in ductility corresponds to the increase in impurity content.

(2) The rupture ductility of the re-heat-treated rotor materilas quenched at $1025^{\circ} \mathrm{C}$ decreases greatly to less than half the value of as-heat-treated materials in (1). The decrease in ductility corresponds to grain growth of prior-austenite grains.

(3) The metallurgical factors that affect rupture ductility remarkably are (a) the pre-austenite grain size corresponding to rotor quenching temperature, and (b) the amounts of impurity, and the smaller (a) is and the lower $(b)$ is, the higher is the rupture ductility.

(4) Consequently a parameter is proposed so that rupture ductility of $\mathrm{Cr}-\mathrm{Mo}-\mathrm{V}$ steel can be obtained, combining both the above-mentioned (a) and (b) factors. This creep ductility parameter, defined as the $Y$-factor, is expressed as :

$Y=0.34[\mathrm{P}]+3.8[\mathrm{~S}]+8.4[\mathrm{Sn}]+12.0[\mathrm{As}]+5.6[\mathrm{Sb}]+2.6$ G.S.

where $[\mathrm{P}],[\mathrm{S}],[\mathrm{Sn}],[\mathrm{As}]$, and $[\mathrm{Sb}]$ are the contents of respective elements (wt.\%), and G.S. is grain size $(\mathrm{mm})$.

Rotor materials of $Y>0.5$ show notch-sensitive behavior, and so the $Y$-factor is effective in judging the notch-sensitive/notch-insensitive property.

Key words : creep; creep ductility; intergranular fracture; $\mathrm{Cr}-\mathrm{Mo}-\mathrm{V}$ steel; notch sensitivity; impurity ; grain size.

\section{1. 緒}

筆者らは先に，実機のロータ材である $1 \mathrm{Cr}-1 \mathrm{Mo}-1 / 4$ $\mathrm{V}$ 龬を用い, $500 \sim 675^{\circ} \mathrm{C}$ の温度範囲でクリープ試験を 行い,クリープ変形とクリープ破断特性を調べて,クリー プ変形の律速過程及びクリープ破断形態は，オロワン応 力を境にして異なることを明らかにした. またたここの 結果によれば $\mathrm{Cr}-\mathrm{Mo}-\mathrm{V}$ 龬が広く使用されている蒸気 タービンロータの使用条件範井は, 上記のオロワン応力
以下にあり, 実用上問題となる破壊機構は破断延性の低 下を伴う粒界破壊であることが予想された.

一方，このクリープ破断延性の変化は, 切欠き部を多 く含むタービンロータの場合には切欠きクリープ破断特 性と密接な関係があると従来から言われている2).これ に加えてクリープ破断延性は最近ではタービンロータの 運用上問題となるクリープ・疲労寿命にも影響を及ぼす との報告3)4もあり，実用上重要な因子と考えられる.

これまで, $\mathrm{Cr}-\mathrm{Mo}-\mathrm{V}$ 鋼のクリープ特性についてはい

平成 4 年 1 月 24 日受付 平成 4 年 6 月 5 日受理（Received on Jan. 24, 1992; Accepted on June 5, 1992)

* 三菱重工業(株)高砂研究所 工博 (Takasago Research \& Development Center, Mitsubishi Heavy Industries, Ltd., 2-1-1

Shinhama Arai-cho Takasago 676) 
ろいろな角度から調べられているが，主に高温強度の観 点から，クリープ強さと組織変化との関係を検討した報 告5) 11) が多い. しかも上述のような実用上問題となる $\mathrm{Cr}-\mathrm{Mo}^{-} \mathrm{V}$ 鋼のクリープ粒界破壊に着目して，粒界に生 じたクリープ損傷を定量的に評価した研究は報告 ${ }^{12) 13}$ されているものの, さらには本鋼種の粒界損傷と破断延 性との関係までを系統的に調べた研究報告は少なく，い まだ不明な点も多い.

ところで， $\mathrm{Cr}-\mathrm{Mo}^{-} \mathrm{V}$ 鋼の粒界破壊を示す場合のク リープ破断延性は，損傷の中味としてのクリープキャビ ティや粒界き裂の発生量に支配されていると考えられる が6)，治金的因子として製造時の熱処理，組織及び合金 成分にクリープ破断延性が影響を受けることはよく知ら れている ${ }^{14)-16)}$. このうち，製造時の熱処理条件につい ては, 過去のロー夕の翼根部の破壊事故調査 ${ }^{2)} の$ 経験等 から，ロー夕の焼入れ温度を $1010^{\circ} \mathrm{C}$ から現在の $955^{\circ} \mathrm{C}$ 付近に下げる処置がとられ，クリープ破断延性は著しく 改善されている．しかしながら，その改善効果が結晶粒 の微細化によるものか, 焼入れ温度における母相への炭 化物の固溶量の差に伴う焼戻し時における炭化物の析出 挙動の変化によるものか，いずれが主たる役割を演じて いるのかに関しては依然として不明である.また,クリー プ破断延性に及ぼす組織及び合金成分の影響について は, その後詳しく調查され，ベイナイト組織の優位性が 確認されるとともに，不純物元素も影響を及ぼすことが 明らかにされている ${ }^{14)}$. 従って，現状では本鋼種のク リープ破断延性に影響を及ぼす治金的因子として，上に 述べた焼入れ温度の影響とロータの溶製間で相違が認め られる不純物元素の影響を取り上げ，これらについて調 べる必要がある. 特に, 不純物元素の影響は興味深いが, これまでの研究は主に不純物元素と寿命や伸びの関係に 集中していた ${ }^{17) 18)}$. 不純物元素と損傷の実体であるク リープキャビティの生成過程との関係付けが重要であ り, とりわけ, 不純物元素量と破断延性との定量的な関 係を合理的な基準に基づいて確立することが重要であ る.

そこで, 本研究では不純物元素含有量の異なる 5 種
類の実機のロー夕材である $\mathrm{Cr}-\mathrm{Mo}-\mathrm{V}$ 鋼を用いて 550 及び $575^{\circ} \mathrm{C}$ において約 $10^{4} \mathrm{~h}$ で粒界破断する応力での クリープ試験を行うとともに，同じ条件におけるクリー プ中断試験片を作製し，クリープキャビティの生成過程 の変化を調べた。さらに，そのうち 3 種類の供試材に ついては，焼入れ温度を $1025^{\circ} \mathrm{C}$ と高くした供試材を 作製し，940 $970^{\circ} \mathrm{C}$ の通常の焼入れ温度のものとのク リープ特性を比較するとともに，クリープキャビティの 生成・成長挙動と破断延性について調へ，それらに影響 する治金的因子の検討を行った.

\section{2. 供試材及び実験方法}

\section{$2 \cdot 1$ 供試材}

供試材は，タービンロータとして 10 万時間程度使用 された 3 種類の実機ロー夕及び 2 種類の製造ままの実 機ロータである.いずれの供試材も $\mathrm{Cr}-\mathrm{Mo}-\mathrm{V}$ 鋼であり, ロータ中心孔近傍からロー夕周方向に試験片を採取し た。実機ロータの試験片採取位置は，長期間使用による 影響を避けるためロータ中心孔の未使用材と同等とみな せる低温低応力部を選んだ．供試材の化学成分を Table 1 に示す。また, Table 1 には各ロー夕材を不純物元素

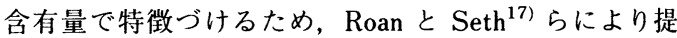
案されている式で定義された全有効不純物含有量 $I_{s}$ を 各ロータ材について算出し併記した。 以下，この表にお いて， Is $>0.6$ に分類されるロー夕材 $\mathrm{A}, \mathrm{C}$ 及び $\mathrm{E}$ を低 純度材， $I_{s}<0.6$ に分類されるロー夕材 $\mathrm{B}$ 及び D を高 純度材と呼ぶことにする。 さらに，供試材のロー夕製造 時の公称の熱処理及び旧オーステナイト粒径を Table 2 に示す。なお，供試材の組織は焼戻しべイナイト組織で ある。

次に, Table 1 に示した供試材の中で, 破断延性の最 も大きいロータ材 D と小さいロータ材 C 及び $\mathrm{E}$ を再 熱処理用の供試材に選んだ。これに Table 3 に示す再 熱処理を施した。すなわち，ロー夕材 $\mathrm{C}$ 及び D は焼入 れ温度を $1025^{\circ} \mathrm{C}$ とし、この温度より冷却後, ロー夕 製造時の素材に施された条件と同一条件の焼戻しを施し

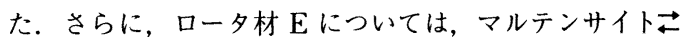

Table 1. Chemical compositions and total effective impurity content of $\mathrm{Cr}-\mathrm{Mo}-\mathrm{V}$ steels studied.

\begin{tabular}{|c|c|c|c|c|c|c|c|c|c|c|c|c|c|}
\hline Rotor & $\mathrm{C}$ & $\mathrm{Si}$ & $\mathrm{Mn}$ & $\mathrm{P}$ & $\mathrm{S}$ & $\mathrm{Ni}$ & $\mathrm{Cr}$ & Mo & $\mathrm{V}$ & $\mathrm{Sn}$ & As & $\mathrm{Sb}$ & $\begin{array}{l}\text { Total effective impurity } \\
\text { content } I_{s}^{*}(\%)\end{array}$ \\
\hline A & 0.28 & 0.20 & 0.79 & 0.027 & 0.013 & 0.39 & 1.05 & 1.15 & 0.24 & 0.018 & 0.021 & 0.003 & 0.97 \\
\hline B & 0.31 & 0.25 & 0.80 & 0.013 & 0.016 & 0.14 & 1.09 & 1.26 & 0.23 & 0.010 & 0.009 & 0.002 & 0.57 \\
\hline $\mathrm{C}$ & 0.30 & 0.25 & 0.75 & 0.008 & 0.008 & 0.35 & 1.23 & 1.20 & 0.26 & 0.017 & 0.016 & 0.003 & 0.62 \\
\hline D & 0.33 & 0.28 & 0.85 & 0.005 & 0.007 & 0.34 & 1.12 & 1.13 & 0.24 & 0.002 & 0.005 & 0.002 & 0.24 \\
\hline E & 0.30 & 0.28 & 0.69 & 0.013 & 0.014 & 0.28 & 1.11 & 1.36 & 0.23 & 0.005 & 0.024 & 0.004 & 0.67 \\
\hline
\end{tabular}

${ }^{*} I_{s}=16.1 \cdot[\mathrm{Sb}]+13.8 \cdot[\mathrm{Sn}]+12.6 \cdot[\mathrm{P}]+10.5 \cdot[\mathrm{As}]+8.8 \cdot[\mathrm{S}] ;$ from ref. 17$)$ 
Table 2. Nominal heat treatment condition and grain size of as-received $\mathrm{Cr}-\mathrm{Mo}-\mathrm{V}$ steels.

\begin{tabular}{c|c|c|c|c}
\hline \multirow{2}{*}{ Rotor } & \multicolumn{2}{|c|}{ Nominal heat treatment } & \multicolumn{2}{c}{ Grain size } \\
\cline { 2 - 5 } & $\begin{array}{c}\text { Austenitising } \\
\text { treatment }\end{array}$ & $\begin{array}{c}\text { Tempering } \\
\text { treatment }\end{array}$ & JIS No. & $\begin{array}{c}\text { Grain diameter } \\
(\mu \mathrm{m})\end{array}$ \\
\hline A & $970^{\circ} \mathrm{C} ; B . C^{*}$ & $680^{\circ} \mathrm{C} ; F . C . * *$ & 4.5 & 90 \\
B & $955^{\circ} \mathrm{C} ; B . C$. & $680^{\circ} \mathrm{C} ; F . C$. & 4.0 & 80 \\
C & $970^{\circ} \mathrm{C} ; B . C$. & $665^{\circ} \mathrm{C} ; F . C$. & 5.0 & 60 \\
D & $955^{\circ} \mathrm{C} ; B . C$. & $680^{\circ} \mathrm{C} ; F . C$. & 3.5 & 100 \\
E & $940^{\circ} \mathrm{C} ; B . C$. & $670^{\circ} \mathrm{C} ; F . C$. & 3.5 & 100 \\
\hline
\end{tabular}

* B. C. : Blast Cooling

** F. C. : Furnace Cooling

Table 3. Re-heat treatment condition and grain size.

\begin{tabular}{|c|c|c|c|}
\hline \multirow[b]{2}{*}{ Rotor } & \multirow[b]{2}{*}{ Re-heat treatment } & \multicolumn{2}{|c|}{ Grain size } \\
\hline & & JIS No. & $\widehat{\substack{\text { Grain diameter } \\
(\mu \mathrm{m})}}$ \\
\hline C & $\begin{array}{l}1025^{\circ} \mathrm{C} \times 10 \mathrm{~h} ; \text { cooling rate } \\
25^{\circ} \mathrm{C} / \mathrm{h}, 670^{\circ} \mathrm{C} \times 50 \mathrm{~h} ; A . C .^{* *}\end{array}$ & 3.0 & 120 \\
\hline D & Ditto & 2.8 & 150 \\
\hline E & $\begin{array}{l}950^{\circ} \mathrm{C} \times 0.2 \mathrm{~h} ; W . Q^{* * *}, 930^{\circ} \mathrm{C} \times \\
0.2 \mathrm{~h} ; W . Q . \times 3,1025^{\circ} \mathrm{C} \times 10 \mathrm{~h}, 670 \times \\
50 \mathrm{~h}, A . C .\end{array}$ & 4.3 & 80 \\
\hline
\end{tabular}

オーステナイトの繰り返し熱処理を施し，前もって結晶 粒径を細粒とした後，上記のロー夕材 C 及び D と同一 の調質処理を施した。なお，焼入れ時の冷却速度は，直 径 $1000 \mathrm{~mm}$ ロータの中心部相当を模擬した. 再熱処理 後の旧オーステナイト粒径を Table 3 に示した.

\section{$2 \cdot 2$ クリープ試験}

試験片は, 直径 $10 \mathrm{~mm}$, 標点間距離 $50 \mathrm{~mm}$ の丸棒試 験片であり，クリープ破断試験には，シングルレバー式 クリープ試験機を用いた。試験温度は 550 及び $575^{\circ} \mathrm{C}$
の 2 温度とした。これらの温度で約 $10^{4} \mathrm{~h}$ で破断するよ うに，試験応力はそれぞれ 210 及び $160 \mathrm{MPa}$ とした. すなわち, 前報1)の結果に基づきクリープキャビティを 伴う粒界破壊で破断する試験条件を選んだ。また，これ らの各条件で破断時間のほほ $1 / 5$ の間隔でクリープ中 断試験片をも作製した。

\section{$2 \cdot 3$ 微細組繶調查方法}

クリープ破断試験片及びクリープ中断試験片を用いて 前報 ${ }^{1)}$ と同様に光学顕微鏡 (光顕), 走査型電子顕微鏡 (走 査電䫓)及び透過型電子顕微鏡 (透過電顕)による組織観 察を行った。これらの試験方法の詳細は前報 ${ }^{1)}$ と同じで ある. クリープキャビティの観察は, 上記試験片の平行 部を縦割りにした面について光顕及び走査電顕により 行った. さらに，観察されたクリープキャビティについ ては, 光顕を用いて $\mathrm{A}$ パラメータ值 ${ }^{19)}$ を計測し, 走査 電顕を用いて単位面積当たりのキャビティ数及びキャビ ティの面積率を計測した. なお，キャビティ数及びキャ ビティの面積率の計測は画像処理装置を用いて行っ た20). また，製造時の熱処理まま材及び再熱処理材の クリープ試験を行った試験片のうち, 一部の試験片につ いては, $5 \%$ 塩酸エチルアルコール溶液を用いて電解抽 出残渣を採取し，X 線回折により析出相を同定した.

\section{3. 実 験 結 果}

\section{$3 \cdot 1$ クリープ試鏂}

本研究で行ったクリープ試験結果を Table 4 に示す. この表のうち, ロータ材 A 及び B のクリープ速度-時 間曲線を Fig. 1 に示す. 前報1)でも述べたが, この図 からわかるように本鋼種のクリープ曲線の遷移クリープ 域は全クリープ域の $20 \sim 30 \%$ を占めており，最小ク リープ速度を示した後は, 定常クリープ域はほとんど認 められず加速クリープ域に移行することが認められた。

Table 4. Creep rupture properties of $\mathrm{Cr}-\mathrm{Mo}^{-} \mathrm{V}$ steels studied.

\begin{tabular}{|c|c|c|c|c|c|c|c|c|}
\hline \multirow{2}{*}{ Heat treatment } & \multirow{2}{*}{ Rotor } & \multicolumn{2}{|c|}{ Creep test condition } & \multirow{2}{*}{ 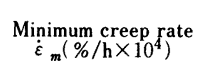 } & \multirow{2}{*}{$\begin{array}{c}\text { Time to rupture } \\
t_{r}(\mathrm{~h})\end{array}$} & \multirow{2}{*}{$\begin{array}{l}\text { Time to onset of } \\
\text { tertiary } t_{t}(\mathrm{~h})\end{array}$} & \multirow{2}{*}{$\begin{array}{c}\text { Elongation } \\
\delta(\%)=\varepsilon_{f}\end{array}$} & \multirow{2}{*}{$\begin{array}{c}\text { Reduction of area } \\
\varphi(\%)\end{array}$} \\
\hline & & $T\left({ }^{\circ} \mathrm{C}\right)$ & $\sigma(\mathrm{MPa})$ & & & & & \\
\hline $\begin{array}{c}\text { Nominal } \\
\left(940 \sim 970^{\circ} \mathrm{C}\right. \\
\text { quenching })\end{array}$ & $\begin{array}{l}\mathrm{A} \\
\mathrm{B} \\
\mathrm{C} \\
\mathrm{D} \\
\mathrm{E}\end{array}$ & $\begin{array}{l}550 \\
575 \\
550 \\
575 \\
550 \\
575 \\
550 \\
575 \\
550 \\
575 \\
\end{array}$ & $\begin{array}{l}210 \\
160 \\
210 \\
160 \\
210 \\
160 \\
210 \\
160 \\
210 \\
160 \\
\end{array}$ & $\begin{array}{l}1.16 \\
2.18 \\
2.94 \\
3.69 \\
3.30 \\
3.26 \\
1.40 \\
2.80 \\
1.90 \\
1.70\end{array}$ & $\begin{array}{r}8195 \\
7063 \\
15323 \\
12102 \\
12768 \\
9694 \\
12645 \\
9226 \\
5653 \\
4434 \\
\end{array}$ & $\begin{array}{l}5900 \\
4200 \\
7600 \\
5400 \\
7720 \\
4840 \\
8400 \\
4700 \\
4700 \\
4100\end{array}$ & $\begin{array}{r}4.4 \\
6.0 \\
14.8 \\
18.7 \\
6.9 \\
6.7 \\
13.8 \\
15.2 \\
4.4 \\
4.6\end{array}$ & $\begin{array}{r}3.0 \\
5.0 \\
41.0 \\
52.0 \\
6.0 \\
4.0 \\
55.0 \\
37.0 \\
6.0 \\
8.0\end{array}$ \\
\hline $\begin{array}{c}\text { Re-heat } \\
\text { (1025 } \mathrm{C} \\
\text { quenching) }\end{array}$ & $\begin{array}{l}\mathrm{C} \\
\mathrm{D} \\
\mathrm{E}\end{array}$ & $\begin{array}{l}550 \\
575 \\
550 \\
575 \\
550 \\
575\end{array}$ & $\begin{array}{l}210 \\
160 \\
210 \\
160 \\
210 \\
160\end{array}$ & $\begin{array}{l}0.78 \\
1.15 \\
0.60 \\
0.88 \\
1.64 \\
2.75\end{array}$ & $\begin{array}{r}13884 \\
9814 \\
20323 \\
13160 \\
11420 \\
8433\end{array}$ & $\begin{array}{r}12600 \\
7800 \\
16300 \\
10100 \\
8000 \\
6830\end{array}$ & $\begin{array}{l}3.2 \\
2.4 \\
5.2 \\
4.8 \\
6.2 \\
6.0\end{array}$ & $\begin{array}{r}5.0 \\
6.0 \\
6.0 \\
7.0 \\
10.0 \\
4.0\end{array}$ \\
\hline
\end{tabular}




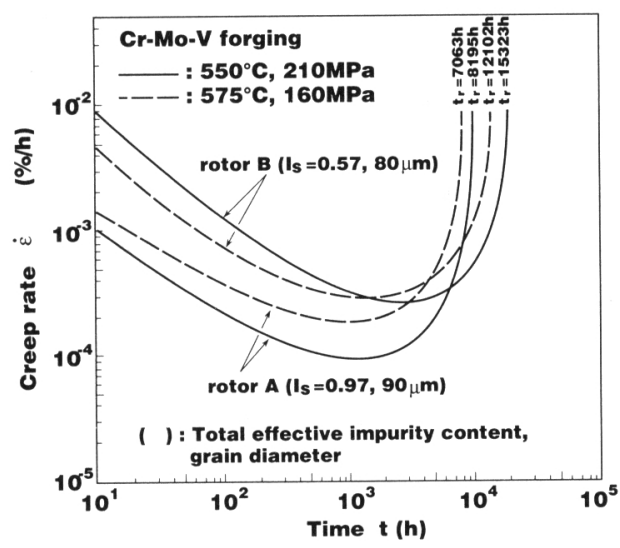

Fig. 1. Creep rate-time curves of rotor $\mathrm{A}$ and $\mathrm{B}$ at $550^{\circ} \mathrm{C}-210 \mathrm{MPa}$ and $575^{\circ} \mathrm{C}-160 \mathrm{MPa}$.

一方，製造時熱処理まま材の破断延性は高純度材であ るロータ材 B 及び D が最も良く, 破断伸びで $10 \%$ 以 上を示した。その他の低純度材のロー夕材は, いずれも 破断伸びが $10 \%$ 以下であった。また，再熱処理を施し たロータ材の破断延性は, ロータ材 $\mathrm{E}$ を除いていずれ も製造時熱処理まま材のそれに比べて $1 / 2$ 以下に大き く減少することが認められた。なお，いずれの破断試験 片も粒界破壊であった。

\section{$3 \cdot 2$ クリープ試験片の抽出レプリカ観察}

製造時熱処理まま材及び再熱処理材のクリープ試験片 の平行部の抽出レプリカによる透過電顕組織については

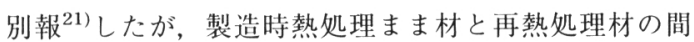
で炭化物の分散状態及び粗大化の傾向に特別な差は認め られなかった。

\section{$3 \cdot 3$ 電解抽出残渣の $\mathrm{X}$ 線回折結果}

製造時熱処理まま材及び再熱処理材のクリープ破断試 験片の平行部から採取した電解抽出残椬の $\mathrm{X}$ 線回折結

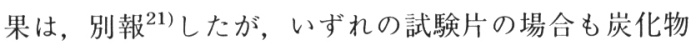

$\mathrm{V}_{4} \mathrm{C}_{3}, \mathrm{Mo}_{2} \mathrm{C}, \mathrm{Cr}_{23} \mathrm{C}_{6}$ 及び $\mathrm{Fe}_{3} \mathrm{C}$ が確認され, 供試材及 びクリープ試験条件の間で析出相の種類及び量に特別な 差は認められなかった.

\section{$3 \cdot 4$ クリープ試験片の薄膜観察}

クリープ試験片の平行部の薄膜による透過電顕組織の

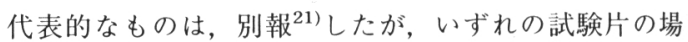
合も試験時間の増加とともに粒界上及び粒内の炭化物は ともにわずかに粗大化し, 特に, 粒界炭化物がその凝集 粗大化の傾向が著しいことが観察されている. また, 試 験時間の増加とともに, 転位密度が低くなる傾向にあり， 炭化物のない領域及びサブグレインが旧オーステナイト 粒界に接して認められ，それらサブグレインは粒内へと 拡大していることも観察された。

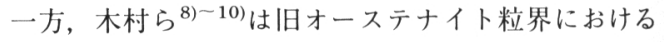
局所的な転位の回復領域に着目し,この回復領域とク リープ速度の増加傾向とがよく対応していることを見い だしている。本研究で用いた抽出レプリカ観察及び薄膜

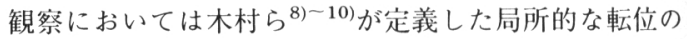
回復領域の幅を明確にかつ精度よく計測できなかった が，検討の余地があろう．

\section{$3 \cdot 5$ クリープキャビティの生成過程の観察}

クリープの各段階で中断した試験片には，いずれもク リープキャビティが認められた。代表的なものとして $550{ }^{\circ} \mathrm{C}-210 \mathrm{MPa}$ におけるクリープ中断試験片に観察さ れたクリープキャビティを Photo. 1 に示す. クリープ キャビティは負荷応力に対する傾きが直角方向に近い粒 界に生成しており, クリープ試験時間とともに，その数 はしだいに増加し, 寸法も大きくなる.しかも, クリー プキャビティは棈円状の形状を保ちながら粒界に沿って 成長し，さらには隣接する成長中のクリープキャビティ と合体してき裂となる。なお，いずれの試験片において も楔型き裂は観察されなかった。

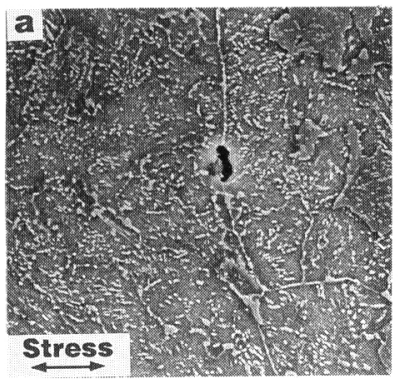

a : $1792 \mathbf{h}(t / t r=0.21)$

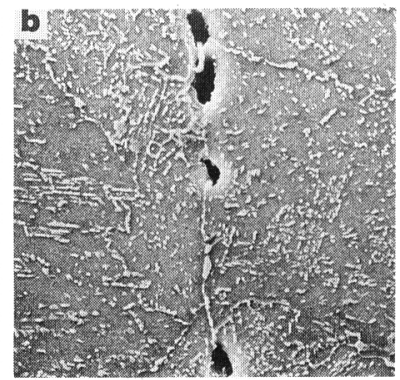

b : $4145 \mathrm{~h}(t / t r=0.50)$

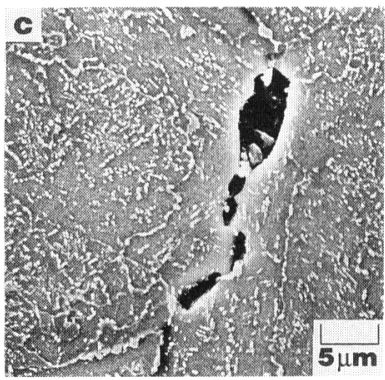

c : $8195 \mathbf{h}(t / t r=1.0$

Photo. 1. Scanning electron micrographs of specimens crept of rotor $\mathrm{A}$ at $550^{\circ} \mathrm{C}-210 \mathrm{MPa}$. 


\section{4. 考察}

\section{$4 \cdot 1$ クリープ特性の旧オーステナイト粒径依存性}

最小クリープ速度の旧オーステナイト結晶粒径依存性 をFig. 2 に示す.この四は, 最小クリープ速度 $\dot{\varepsilon}_{m}$ と 結晶粒径 $D$ を $\log \dot{\varepsilon}_{m}-\log D$ の関係で示したものであ る. 本研究で試験した $60 \mu \mathrm{m} \sim 150 \mu \mathrm{m}$ の範囲内では最 小クリープ速度は旧オーステナイト粒径の増加に伴い直 線的に減少し，その勾配は約 -2 である。

クリープ速度やクリープ破断強度におよぼす旧オース テナイト結晶粒径の影響の中には他の因子による影響が 含まれる場合もある．例えば，本鋼種の場合には前述し たようにロータの焼入れ温度の違いによって旧オーステ ナイト粒径も変わるが, 同時に母相への炭化物の固溶量 も変化するため, 固溶強化や析出強化の寄与が変わるも のと考えられる. 本研究では, それら旧オーステナイト 粒径および母相の炭化物などの変化を分離してクリープ 特性におよほす寸効果を調べるため, Table 3 に示した再 熱处理を施した。すなわち, Table 3 でロー夕材 $\mathrm{E} に$ ついては，熱处理により前もって結晶粒径を細粒とした 後, 他のロータ材 $\mathrm{C}$ 及び $\mathrm{D}$ と同じ焼入れ温度 $1025^{\circ} \mathrm{C}$ の調質処理を施した. 従って, 再熱处理材は母相の炭化 物の固溶量を同一とし, 旧オーステナイト粒径のみ変化 させた供試材となっている. 実際に, 抽出レプリカ観察 結果及び電解抽出残渣の $\mathrm{X}$ 線回折結果からも再熱処理 材のロー夕材の間で炭化物の分散状態, 種類及び量に特

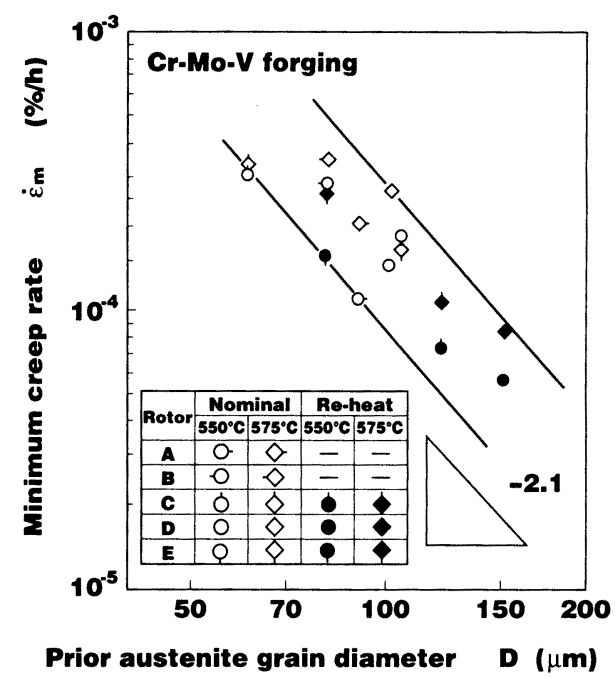

Fig. 2. Relation between the minimum creep rate at $550^{\circ} \mathrm{C}-210 \mathrm{MPa}$ and $575^{\circ} \mathrm{C}-160 \mathrm{MPa}$ and prior austenite grain size.
別な差は認められていない. 再熱処理材の結果は, Fig. 2 には黒塗りで示したが, これらのロータ材の間におけ る最小クリープ速度の差は明らかに旧オーステナイト粒 径のみの影響と考えられる。

\section{$4 \cdot 2$ キャビティの生成過程とクリープ挙動}

本研究で実施したクリープ試験条件下でのクリープ変 形は別報11で述べたように転位密度の減少とサブグレ インを伴う転位組織の回復が支配する機構により生じて いると推論されるが，同時にクリープ損傷としては粒界 にクリープキャビティが生成・成長する，クリープキャ ビティの発生及び成長機構は不明な点が多いのが現状で あるが, その中でも後者の成長機構に関する研究は盛ん である ${ }^{23)}$. 提唱されているクリープキャビティの成長 機構モデルのひとつに組合せモデル ${ }^{23)}$ がある. すなわ ち，このモデルはマトリックスの変形や粒界すべりに関 連した变形依存性の因子と拡散に関連した時間依存性の 因子が重なり合ったモデルであり，後述するようにク リープキャビティの生成・成長挙動の特徴をかなりよく 説明できる.

$\mathrm{A}$ パラメータ, キャビティ数及びキャビティの面積 率で表示したクリープキャビティの生成過程は, クリー プひずみの関数だけで単純に比例関係で整理し得なかっ たので，上述の組合せモデルを考虑してクリープ損傷の 時間あるいはひずみに対する依存性の観点から，時間と ひずみの積 $\left(t \times \varepsilon_{c}\right)$ に対して対数でプロットしてみた. A パラメータで整理した場合の結果を Fig. 3 に示す. キャビティ数及びキャビティの面積率で整理した場合の 結果は，別報21)したが，いずれの場合もかなりのばら つきはあるものの対数表示に対して直線近似が可能であ る.これらの図中の線群は，クリープ損傷が時間とひず みの積の $n$ 乗に比例し, かっ $n=1$ であることを示し

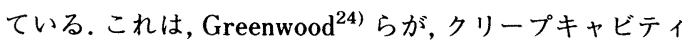
の生成速度はクリープひずみ量に比例し，成長は単純な 粒界拡散モデルによって支配されるとした考え方に対応 している.

Fig. 3 からわかるように，粒界損傷量を示す A パラ メータ值は, 時間とひずみの積に比例し, 図中直線群で

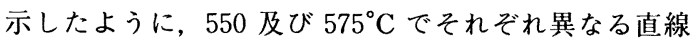
となるような温度依存の傾向が認められた。また， A パラメータで整理すると高純度材及び低純度材の材料の 組成依存差は認められず, 直線群の中をばらついている.

さらに, 別報 ${ }^{21)} に$ 示したが, キャビティ数及びキャ ビティの面積率で整理した場合は，Fig. 3 で認められ た温度依存性の他にも高純度材と低純度材の材料の組成 依存性も認められた。低純度材のキャビティ数及びキャ 


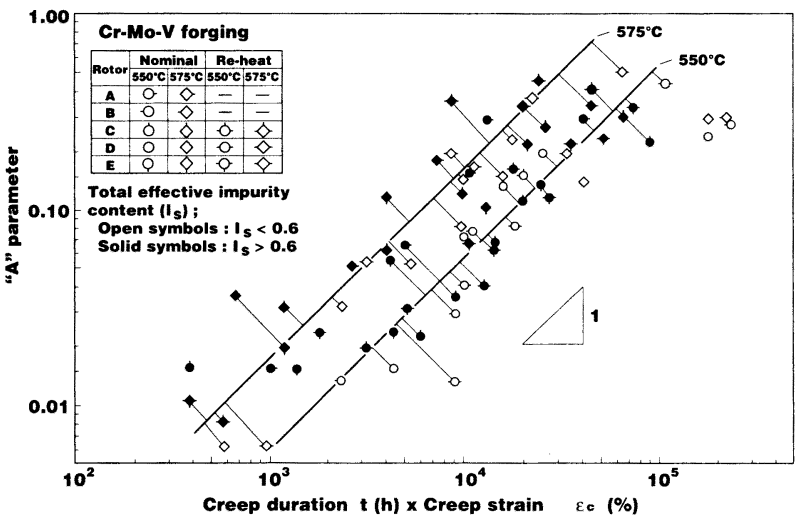

Fig. 3. Relation between "A" parameter and creep duration $\times$ creep strain.

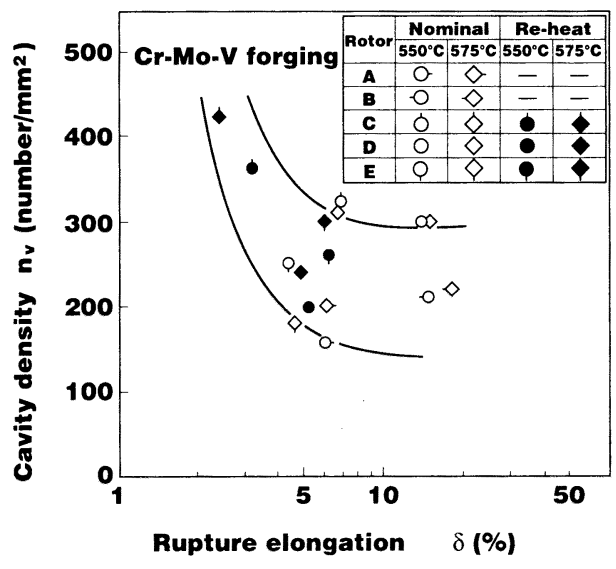

Fig. 4. Effect of cavitation on rupture ductility.

ビティの面積率は，高純度材のそれに比べて約 2〜4 倍 程度大きくなっている ${ }^{21)}$ 。これらのことから，キャビ ティ発生と成長には, P, S, Sn, Sb, As などの不純物元 素が強く影響を及ほし，これら不純物元素の多いものほ どキャビティの発生と成長が活発になるものと考えられ る.つまり，不純物元素は粒界に偏析し表面エネルギー や粒界エネルギーを減じ，その結果キャビティはより小 さい安定キャビティ寸法及びひずみで発生し，その核生 成の割合も大きくなるために上述のような結果になった ものと推定される.

次に，破断時のキャビティ量を破断延性に対して整理 した結果を Fig. 4 に示す。この図は，キャビティ数と 破断伸びの関係を示したものであるが, クリープキャビ ティの生成に伴ない破断延性が低下寸る傾向が認められ る. また, 京野ら ${ }^{25)}$ も $\mathrm{Cr}-\mathrm{Mo}-\mathrm{V}$ 鋳鋼で調べ同様な結果 を報告しているが，粒界き裂及びクリープキャビティが 粒界破壊を招き破断延性を低下させるものと考えられ
る。

\section{$4 \cdot 3$ 破断延性に影䈏する治金的因子}

前節で述べたように， Cr-Mo-V 鋼における粒界破壊 を示す場合のクリープ破断延性は，クリープキャビティ や粒界き裂に支配されていると考えられる，前節までに 得られた結果及び従来の知見に基づき $\mathrm{Cr}-\mathrm{Mo}^{-}-\mathrm{V}$ 鋼の破 断延性に対する治金的因子の影響をまとめ，次の 2 項 目について考えてみる。

( 1 ) ロー夕の焼入れ温度の影響

( 2 ) ロー夕の不純物元素の影響

まず(1)の項目に関しては，前にも述べたようにク リープ破断延性に対して旧オーステナイト粒径の変化と 炭化物の種類の変化とのいずれが主たる役割を演じてい るのかが問題である．本研究で得られた結果の範囲内に おいては, 後者の炭化物の種類の影響は少なく, 前者の 旧オーステナイト粒径のみが支配的因子と考えて差しつ かえない，そこで，本研究で得られたクリープ破断伸び を旧オーステナイト粒径で整理し Fig. 5 に示す。この 図から，破断伸びは細粒ほど大きく，粗粒ほど小さくな ることがわかる．また同時に，この延性の傾向には，材 料の組成依存性があり, 高純度材と低純度材の 2 群に 分けられ，不純物元素の影響も顕著である，粗粒になる ほど破断伸びが低下する現象は，以下のように説明され る.すなわち, 粒界すべりがキャビティ生成に関係して いると仮定すると，粗粒のものほど粒界すべり量が大き くなり ${ }^{26)}$, キャビティの発生及びき裂の進展速度が大 きくなり，最終的に破断延性が低下する.

次に( 2 )の項目については, $\mathrm{Cr}-\mathrm{Mo}^{-} \mathrm{V}$ 鋼における $\mathrm{P}$, $\mathrm{S}, \mathrm{Sn}, \mathrm{Sb}, \mathrm{As}$ などの微量不純物元素の破断延性への影 響は比較的よく調べられており，これらが増加すると破 断延性を低下させることやクリープキャビティの生成. 成長を促進させることなどが報告されている ${ }^{17) 18) 25)}$. 


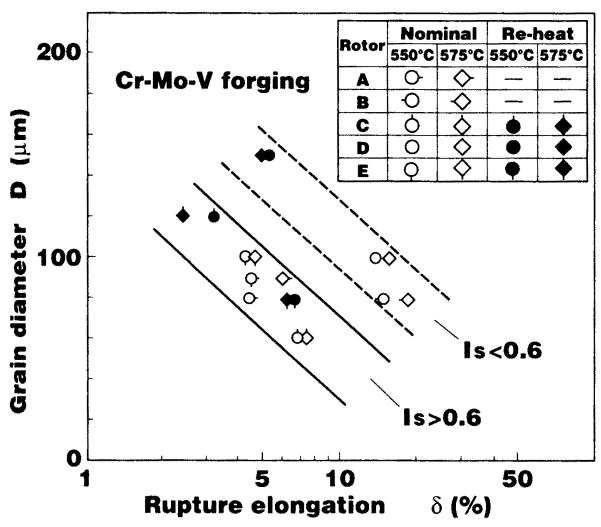

Fig. 5. Effect of prior austenite grain size on rupture ductility.

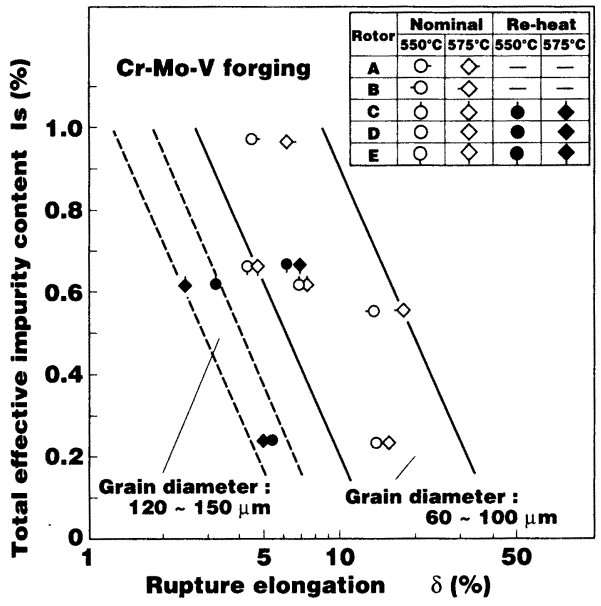

Fig. 6. Effect of total effective impurity content on rupture ductility.

本研究で得られたクリープ破断伸びを Roanと Seth ${ }^{17)}$ らにより提案されている全有効不純物含有量 $I_{s}$ で整理 し Fig. 6 に示す.この四から，破断伸びは $I_{s}$ が大きく なるほど，すなわち不純物元素含有量が多くなるほど小 さくなることがわかる. また，同じ記号の白ヌキ符号と 黑塗り符号を比較すると $I_{s}$ が等しいにもかかわらず, 破断伸びは大きく異なり，不純物元素含有量だけでは破 断伸びを整理することはできない。そして，図中に破線 及び実線のバンド線を引いたようにこの延性の傾向は， 旧オーステナイト粒径の影響も顕著であり，粗粒と細粒 の 2 群に分けられる. 不純物元素含有量が多くなるほ ど破断伸びが低下する現象は，以下のように説明される. すなわち, P, S, Sn, Sb などは粒界に偏析し，表面エネ
ルギーを小さくするとされているが，これが小さくなる とキャビティはより小さい安定キャビティ寸法及びひず みで発生し，さらにき裂成長速度及びキャビティの発生 速度は増大する．この現象は定性的には前節で述べたよ うに本研究において確認されているが，実際に粒界の不 純物偏析量を調べた例 ${ }^{25)}$ は少ない.

以上のことから，上記（1）及び（2）の因子をあわ せて $\mathrm{Cr}-\mathrm{Mo}^{-} \mathrm{V}$ 鋼の破断延性を推定する指標を次のよう にして求めた.まず, Table 4 に示したクリープ破断デー 夕の他に金材技研の $550^{\circ} \mathrm{C}-196 \mathrm{MPa}$ のクリープ破断 データ ${ }^{26)}$ 及び $\mathrm{Tu}$ と $\mathrm{Seth}^{18)}$ の行った $566^{\circ} \mathrm{C}-262 \mathrm{MPa}$

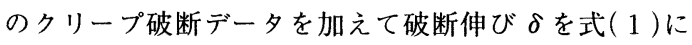
示すような $\mathrm{P}, \mathrm{S}, \mathrm{Sn}, \mathrm{As}, \mathrm{Sb}$ の各不純物元素と結晶粒 径で表示する回帰式を求めた.ここで, $\delta_{0}$ は定数, $[\mathrm{P}]$, [S], [Sn], [As], [Sb] は各元素含有量 (wt.\%), G.S. は 結晶粒径 $(\mathrm{mm})$ である.

$$
\begin{aligned}
\delta & =\delta_{0}-\left(a_{1}[\mathrm{P}]+a_{2}[\mathrm{~S}]+a_{3}[\mathrm{Sn}]+a_{4}[\mathrm{As}]\right. \\
& \left.+a_{5}[\mathrm{Sb}]+a_{6} \text { G. S. }\right) \cdots \cdots \cdots \cdots \cdots \cdots \cdots \cdots \cdots \cdots \cdots \cdots \cdots \cdots \cdots \cdots \cdots \cdots \cdots \cdots \cdots \cdots
\end{aligned}
$$

次に, 式( 1 )により回帰式の各係数を求め, 式( 1 )の右 辺の第 2 項を $Y$ と置き, 次式で表示した.

$$
\begin{aligned}
Y & =0.34[\mathrm{P}]+3.8[\mathrm{~S}]+8.4[\mathrm{Sn}]+12.0[\mathrm{As}] \\
& +5.6[\mathrm{Sb}]+2.6 \text { G.S. } \cdots \cdots \cdots \ldots \ldots \ldots \ldots \ldots \ldots . .
\end{aligned}
$$

上記（2）式をクリープ延性パラメータ，Y-因子と定 義した. 各材料ごとにY-因子を求めて破断伸びとの関 係で整理した結果を Fig. 7 に示す.また, 平滑試験片

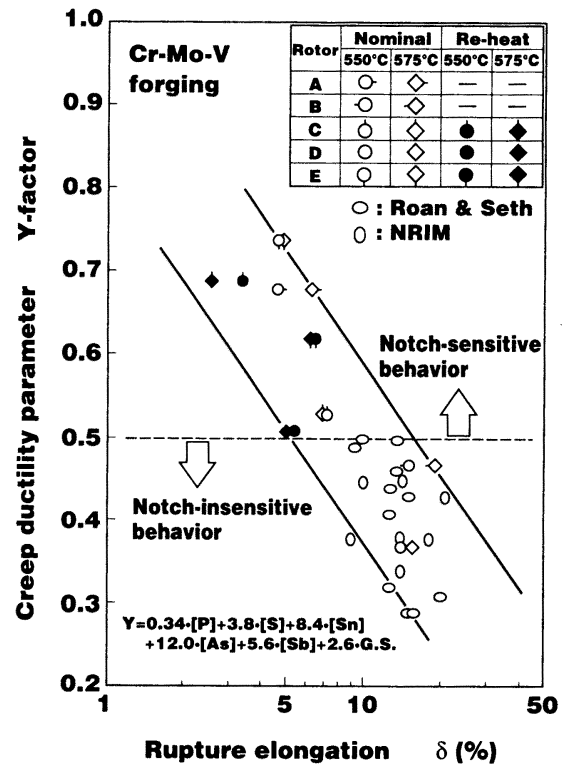

Fig. 7. Relation between creep ductility parameter and rupture elongation. 
と同じ条件で実施した切欠きクリープ破断試験は，製造 時熱処理まま材のロー夕材 B 及び D 材以外はいずれも 切欠弱化であった。 その結果に基づけば，Fig. 7 には 切欠弱化傾向を示す領域とそうでない領域を $Y=0.5$ を基準にして工学的に区分される．なお，経年劣化調査 の対象となる古いロー夕は， $Y=0.5$ を超すものもある が, 最近の新製ロー夕は, いずれも $Y=0.5$ 以下であり, 切久弱化の問題はない.

\section{5. 結}

\section{言}

焼入れ温度が異なり，かつ不純物元素含有量の異なる 実機のロータ材である Cr-Mo-V 鋼を用いて 550 及び $575^{\circ} \mathrm{C}$ において約 $10^{4} \mathrm{~h}$ で粒界破断する応力でのクリー プ試験を行い, クリープ特性を比較するとともに,クリー プ過程中のクリープキャビティの生成・成長挙動と破断 延性について調へ，それらに影響する治金的因子を検討 した結果，以下の結論を得た.

(1)製造時熱処理まま材の破断延性は高純度材が最も 良く，破断伸びで $10 \%$ 以上示した。その他の低純度材 のロー夕材は，いずれも破断伸びが $10 \%$ 以下であり， この低下は不純物元素含有量が増加するのと対応する.

（2）1025 $\mathrm{C}$ 焼入れの再熱処理を施したロータ材の破 断延性は，微細化を図ったロー夕材を除いていずれも 940 970 $\mathrm{C}$ で焼入れた製造時熱処理まま材のそれに比 べて $1 / 2$ 以下に大きく減少し，この低下は旧オーステ ナイト粒径が粗大化するのと対応する.

( 3 )旧オーステナイト粒径の増加に伴い, 最小クリー プ速度は減少する.

(4)クリープキャビティは時間とひずみの積に比例し て生成・成長する。 また，それらが粒界破壊を招き破断 延性を低下させる。

（5)破断延性に著しく影響する冶金的因子として（a） ロー夕の焼入れ温度に対応した旧オーステナイト粒径の 大きさ及び (b) P, S, Sn, As, Sb などの不純物元素量が あり，（a）が小さく（b）が少ないほど破断延性は大きく なる.

（６）以上のことから，上記（５）の（a）及び（b) の因 子をあわせて $\mathrm{Cr}-\mathrm{Mo}^{-} \mathrm{V}$ 鋼の破断延性を推定する指標と してクリープ延性パラメータ， $Y$-因子を提案した， $Y$ は次式で表される.

$$
\begin{aligned}
Y & =0.34[\mathrm{P}]+3.8[\mathrm{~S}]+8.4[\mathrm{Sn}]+12.0[\mathrm{As}] \\
& +5.6[\mathrm{Sb}]+2.6 \text { G.S. }
\end{aligned}
$$

ここで, $[\mathrm{P}],[\mathrm{S}],[\mathrm{Sn}],[\mathrm{As}],[\mathrm{Sb}]$ は各元素含有量 (wt.\%) 及び G. S. は結晶粒径 $(\mathrm{mm})$ である.この $Y$ が, $Y=0.5$ を超えるロー夕材は切欠弱化傾向を示し, $Y$-因子は切欠弱化/強化の判定に有効である.

終わりに，本論文をまとめるに際し，有益なご助言を いただきました東京工業大学工学部 菊池 實教授に深く 感謝します

\section{文献}

1) 角屋好邦，後藤 徹: 鉄と鋼，76（1990), p. 1171

2 ) J. D. Conrad and N. L. Mochel: Trans. ASME, 80 (1958), p. 1210

3 ) T. Endo and T. Sakon: International Conf. on Creep (1986), p. 263

4 ）山口弘二, 鈴木直之, 井島 清, 金沢健二: 鉄と鋼, 71 (1985), p. 1526

5 ) K. R. Williams: Mater. Sci. Eng., 28 (1977), p. 2892

6 ) N. Shinya and S. R. Keown: Met. Sci., 13 (1979), p. 89

7 ）松尾 孝，木佐貫哲也，田中良平，小松周一: 鉄と鋼，70 (1984), p. 565

8 ）木村一弘，木佐貫哲也，小松周一，松尾 孝，田中良平: 鉄と鋼, 71 (1985), p. 1803

9 ）木村一弘，松尾 孝，菊池 實，田中良平: 鉄と鋼，72 (1986), p. 474

10）木村一弘，大井成人，松尾 孝，菊池 實，田中良平: 鉄と鋼，74（1988），p. 1641

11) D. A. Miller, W. T. Plumbridge and R. A. Bartlet: Met. Sci., 15 (1981), p. 413

12) H. R. Tipler and B. E. Hopkins: Met. Sci., 10 (1976), p. 47

13）新谷紀雄, 京野純郎, 横井 信: 鉄と鋼, 70 (1984), p. 573

14) F. E. Werner, T. W. Eichelberger and E. K. Hann: Transaction of the ASM, 52 (1960), p. 376

15) J. F. Norton and A. Strang: J. Iron Steel Inst., 207 (1969), p. 193

16) P. G. Stone and J. D. Murray: J. Iron Steel Inst., 203 (1965), p. 1094

17) D. F. Roan and B. B. Seth: ASME, MPC-8-7 (1978), p. 79

18) L. K. Tu and B. B. Seth: Met. Technol., 5 (1978), p. 79

19）角屋好邦，後藤 徹: 材料, 36 (1987), p. 999

20）角屋好邦, 後藤 徹, 飯田泰久, 釣戻太郎, 春木仁朗, 生野 建: 材料とプロセス, 4 (1991), p. 814

21）角屋好邦, 後藤 徹: 学振 123 委研究報告, 32 (1991), p. 149

22）松尾 孝，木村一弘，㐘池 賽: 電気製鋼，58（1987）, p. 94

23）堀内 良, 大塚正久: 日本金属学会会報, 22 （1983）, p. 293

24) G. W. Greenwood: Phil. Mag., 19 (1969), p. 423

25）京野純郎，新谷紀雄，九島秀昭: 鉄と鋼，75 (1989), p. 972

26）須藤 一: 日本金属学会会報, 5 (1966), p. 379

27) NRIM Creep Data Sheet No. 9B (1990) 